\title{
Internal Colonization and the Phenomenon of Moscow-phobia in Russian Province Regions ${ }^{1}$
}

\author{
Nadezhda K. Radina \\ National Research University Higher School of Economics, Department of \\ Social Sciences, Nizhny Novgorod, Russia \\ e-mail:rasv@yandex.ru
}

\author{
Mariia V. Koskina \\ State University of New York at Binghamton, Department of History, \\ Binghamton, USA \\ e-mail: mariakoskina00@gmail.com
}

\begin{abstract}
The article presents the results of investigation of the social phenomenon of Moscow-phobia based on empirical data that include 881 interviews taken in the Nizhny Novgorod region in 2002 and 2014. The analysis of Moscow-phobia builds on Alexander Etkind's thesis that internal colonization reproduces cultural distance.

The findings are explained in the context of two theories of internal colonization, Marxist and post-colonial. Earlier, Rossman described five concepts of Moscow-phobia based on territorial economic inequalities and the political hegemony of the center.

This study complements the list with the new forms, as the participants express their anxiety centered on the cultural distance and the domination of province.

Thus, the central argument of this article is that contemporary Russia incorporates both trends (decolonization and reproduction of internal colonialism) in the relationship between the "center" (the capital) and the "periphery" (the regions).
\end{abstract}

Key words: internal colonization, Moscow-phobia, capital, city, territorial inequality.

\footnotetext{
1 This study (research grant № 14-03-00617 "Regional Identity in the Conditions of Social and Economic Changes (Nizhny Novgorod case 2002 - 2014)") supported by the Russian Foundation for Humanities 2014/2015.
} 


\section{Introduction}

The studies that claim to produce "knowledge about the city", regardless of the subject area (architecture, geography, sociology, etc.), are usually done on the basis of specific cities. Thanks to these studies, many already well-known cities have gained special fame in academia. Among the most famous cities represented in urban studies are Paris (Harvey, 2003), Los Angeles (Davis, 2006), San Francisco (Etbington, 2001), London (Onega and Stotesbury, 2002), St. Petersburg (Vakser, 2006; Rubl, 2002) and others.

Researchers more often focus on touristic, renowned cities and capitals. Moreover, the researchers have analyzed and described particular capitals in such detail, that they started to overshadow other cities and even the image of the whole country (Rossman, 2013). Nevertheless, the subject of metropolitan area is extremely important for urban planning, since capitals refer to the "special class of cities" (Campbell, 2013).

This article features the results of a study that reveals ambiguous relations between the capital (Moscow) and non-capital Russian cities as viewed by the residents of peripheral Russian regions. The interpretation of this phenomena relies on the theory of internal colonization which acquires peculiar characteristics based on Russian material (Gouldner, 1978; Rodoman, 1996; Etkind et al., 2012).

The paper starts with the description of the key theoretical ideas that were used to translate empirical facts into scientific interpretations. The studied ambiguous relations of the residents of Russian peripheral regions towards the capital were identified empirically and defined as "Moscow-phobia" (a phenomenon commonly known in Russia largely from mass media discourse). The phenomenon of Moscowphobia was theorized in the context of colonial relations. Next, the program of empirical research and the discussion of its results will be presented. In conclusion, the phenomenon of Moscow-phobia will be inscribed into the conceptual space of internal colonization in the context of scientific discussions about the national specifics of relations between the center and the regions.

\section{Theoretical Field}

\section{1. "Center - Periphery" Construct}

The most general concept that is essential for the analysis of relations between regions is the relationship between the center and the regions. The dichotomous "center-regions" construct constitutes a number of research programs in area studies, although in some concepts and theories it is complicated by the weakening of the dichotomy and by the addition of various semi-peripheral areas to analysis (Wallerstein, 2004). 
The scholarship of relations between the center and the periphery engendered some traditions that allow us to classify concepts and theories about center-peripheral relations in a certain way. Available theories can be divided into universal and specialized. Universal theories, such as the Eisenstadt's typology describing two types of center-peripheral systems (Eisenstadt, 1981), are relevant for the analysis of the problems between unions, countries, and between territories within one country. Specialized theories explain territorial relations, for instance exclusively on the geopolitical level, such as the concept of peripheral capitalism (Bowles, 1989; Prebisch, 1992), or focus on the characteristics of interaction among local territories within a larger entity, like the theory of internal colonization (Blauner, 1972; Gramsci, 1957; Hechter, 1975 et al.).

Spaces and territories are objectively differentiated; they have different parameters, functions and properties. Relations between the central territories (the "center") and marginal territories (the "periphery") make up the field of interdisciplinary interest and are studied at the intersection of the disciplines such as geography, economics, politics.

The "centrality" of a territory is secured by the concentration in it of a significant amount of resources for development (labor, economic, social, managerial, information, intellectual, organizational). The center becomes the main generator of production capacities, innovative ideas and other social benefits, market and entrepreneurial activity, information and communications, etc. According to traditional conceptions, the periphery is characterized by catching-up way of development and mainly low dynamics of managerial processes, remaining on subordinate, auxiliary and serving roles.

The most famous theoretical paradigms in the study of "center-periphery" relations, as a rule, are classified as follows:

- concepts and theories that take into account the historical dimension of "centerperiphery" relations (for example, the theory offered by Rokkan and Urwin who studied the historical-geographical process of state building in Europe) (Rokkan and Urwin, 1996);

- concepts and theories that focus on the analysis of territorial management functions (for example, Hartshorne's concept of regional management in a state) (Hartshorne, 1950)), including the models and concepts employed for analysis of relations between capitals and regions (Taylor, Catalano, Walker, 2002);

- concepts and theories that involve socio-economic aspects of center-region relations (for example, Friedmann's theory of a technologically advanced center and a backward, underdeveloped marginal territories with retarded modernization) (Friedmann, 1966).

The paradigms oriented to socio-economic analysis of the development in the center and other territories include the theory of internal colonization. This theory explains the causes of territorial inequality, as well as the social consequences of territorial hierarchies (Hechter, 1975). 


\subsection{Theoretic Coordinates of Internal Colonization}

In Russian historiography, the term "internal colonization" is closely related to the name of the historian Kliuchevskii. The latter used the thesis of a philosopher Soloviev on the history of Russia as a country that is constantly being colonized: the colonization area is expanding along with the state territory (Kliuchevskii, 1956). According to established definitions, colonization is a historical process of territorial accession characterized by the growth of state population, while colonialism is the ideological design and rationale for relations of dominance among theories (Etkind, Uffelmann, Kukulin, 2013).

When analyzing various aspects of internal colonization in the context of colonial relations, researchers identify hierarchies of territories, relations of domination, subordination and exploitation, and then, they try to define the identified relations of exploitation.

Marxian traditions of the late nineteenth century shed light on the relations of economic inequality between the center and the colonized (peripheral) regions making the conclusion about economic exploitation of peripheral regions as a key characteristic of colonial relations in the process of internal colonization.

V. Lenin formulated one of the most famous versions of Russian internal colonialism that was essentially economic (Lenin, 1971). According to this version, in imperialist power, even the proletariat of the metropole, is subsidized by the proletariat of exploited colonies. In connection with Marxist traditions, internal colonialism is generally defined through economic terms and through political terms of hierarchy and inequality, as an economic exploitation of periphery or province by the "center". This exploitation in its turn is described in terms of economic, political and cultural dependence (Vagin, 1997).

Gramsci (1957) followed the Marxian approach examining internal colonization (through the example of Northern and Southern Italy) and economic determination of the cultural sphere (hegemony) and political sphere (domination) of peripheral regions. At the same time, neo-Marxism reinterprets traditional schemes for analysis of internal colonization, paying special attention to cultural transmission (Habermas, 2004).

The current theoretical scope of the phenomenon of internal colonization is quite dense and diverse. Nevertheless, it is not the economic, but the cultural factor that becomes decisive in the theories of internal colonization of the second half of the twentieth century.

In his analysis of internal colonialism in the United States, Blauner regarded African American population as an exploited group. Here, the components of colonial relations presupposed the compulsory imposition of dominant culture by colonialists (their importation into the metropole as slaves), attempts by the dominant culture to change and control indigenous culture, political domination, economic exploitation, and ideology that justified the authority of the dominant group (Blauner, 1972). 
Hechter developed his concept of internal colonization with reliance on the culture studies theory (Hechter, 1975:22-34). In his interpretation, the economic dependence of the periphery on the center is supported with legal, political and military measures. The overall economic inequality between the core and the periphery is determined by cultural differences. With internal colonialism understood this way, the development of the territory is determined not by socio-structural or economic processes, but by the state control over the distribution of resources.

In modern studies, the conceptual apparatus of internal colonialism is used in discussions around the problems stemming from the relations between the "golden billion" and the rest of the world (Walls, 2008; Calvert, 2001; Netzloff, 2003).

The emphasis on culture in recent studies of internal colonization can be explained by the practice of "postcolonial view" on colonial relations. Postcolonial theory, which took shape in the late twentieth century (Fanon, 2008; Said, 1994, 1998, 2003; Spivak, 1998, 2006), highlighted the cultural and ideological dimensions leading to the understanding of colonialism as a "system of discursive exercise of power" (Fisher-Tine, 2010; Ashcroft et al., 1995).

The key markers of postcolonial studies approach include the actual denial of possibility of universal truths and stable epistemological foundations, as well as the recognition of linguistic conception of reality and the inevitable relativity of all knowledge. Among the most common interests in postcolonial research, are the experiences of "silenced", insufficiently represented or unrepresented cultural groups, whose history was associated with political, social, cultural and psychological suppression and thus generated controversy. The emphasis on the complex interaction between the culture of a colonizer and the culture of the colonized, that can take a variety of forms, from assimilation to transculturation, is essential for postcolonial theory.

\subsection{Theory of Internal Colonization in Russian Studies}

The idea of internal colonization has appeared in a number of works in Russian Studies.

Looking at the culture of Russian cities from the historical perspective, an art critic, media theorist and philosopher Boris Grois discovered the phenomenon of self-colonization. Grois points out to the divergence between the city of Saint-Petersburg, a kind of a European colony on Russian territory, and the rest of the country, the cultural gap between the elites and the peasanty, that resulted from Peter the Great's efforts to emulate the Western model of modernization (Grois, 1993:358). Grois argues that such internal colonization of Russia by its own people, the progressive intelligentsia that seemed to be rather foreign, immunized the empire against the "real" European colonization. Interestingly, at the end of the nineteenth and the beginning of the twentieth century another Western idea, the Marxism, gained popularity in Russia and spread from the largest cities. According to Clark, in the 1930-s, 
the Soviet officials promoted then the cultural "cult of Moscow" as a "paradigm of the Soviet beauty"; against the background of central planning of economy and the newly developed system of collectivized agriculture Moscow established itself as a metropole, the center of economic planning and cultural production in Russia (Clark, 2011).

Gouldner linked the internal colonization with Stalinism arguing that during the revolution, Russian society was represented mainly by peasants, while the Communist party was isolated and elite, claiming to represent a small group of proletariats (Gouldner, 1978). It was the politics of internal colonialism that engendered collectivization. The peasants were the majority; they resisted the Soviet policies and denied the new Bolshevik culture. Thus, Stalin needed to discriminate against the peasants, making them the lowest class. Gouldner calls peasants the Russian Indians, and the Russian village - a reservation.

Etkind proposed another theory of internal colonialism in the Russian Empire focusing on cultural hegemony and political domination of the "center" (Etkind, 2011). In his research, Etkind paid considerable attention to constructed and reproduced cultural differences and cultural identity in the context of internal colonialism in the Russian Empire. According to him, all forms of domination, maintenance of inequality, and exploitation of the colonized are possible only when a huge cultural gap divides the elites from the common people. The question remains open however, how relevant is the phenomenon of internal colonization described by Etkind regarding the Russian Empire for relationships between Moscow and the "Russian province" today?

Said (1994) analyzed the construction of the "colonized other" in Orientalism and Culture and Imperialism where he repeated in various forms the same idea. While exploring and reflecting on the relationship between the colonizers and the dominated colonized subjects, the colonizer is not simply creating a way to understand the relations between unequal communicators, but also reconstructs the meanings of cultural practices. Therefore, the theories about the history and culture of oppressed nations may be challenged by these same nations. The concept of "middle ground" was offered to explain the relations between various colonized groups, as it describes the process of understanding between the oppressed (White, 2011). Finally, the study of anti-colonial resistance now includes not only open forms of protest, but the countless forms of rejection, escape, evasion, fraud, passive response (some authors consider any speech acts of the colonized a form of resistance) (Steinman, 2016).

In terms of the relations between the Russian regions (Zubarevich, 2010), the idea of the resistance to the reproduction of imperial colonial practices helps to explain the phenomenon of the Moscow-phobia that is insufficiently studied, but rather typical for the post-Soviet space (Rossman, 2013). Rossman was one of the first to use the concept of the Moscow-phobia in his academic and publicist works; following his lead we will refer to this phenomenon as either rational or irrational fear or dislike of Moscow. As a rule, the aversion towards the colonizers is described on material 
of non-European "barbarians" and "savages", backward and uncivilized peoples (Davidson, 2007:60-75). The interpretation of center-periphery relations in Russia in terms of the colonial relationship however, allows us to consider the Moscowphobia as "the other" a marker of colonialism in imperial space.

Rossman identified the following forms of negative attitudes of provincial Russians towards Moscow and the Muscovites (five concepts of the phobia of Moscow) (Rossman, 2014):

- the concept of "parasitic capital" (Moscow is perceived as a city that takes advantage of the whole country, living at the expense of other regions);

- the concept of an alienated "state within a state" (Moscow is perceived as an isolated capital, unfamiliar with national problems; according to the VTsIOM opinion poll, $75 \%$ of Russian citizens "do not like" the Muscovites and attribute to them perverse moral qualities; many Russians have never been to the capital because of the low economic standard of living in the province);

- the concept of Moscow as a Western cosmopolitan power representing the Western "comprador" capitalism²;

- the concept of Moscow as a city characterized by the blasphemous demonstrative consumption of Russian elites;

- the concept of Moscow as a drain that pulls in economic, as well as human resources from the surrounding regions, depleting these regions.

According to Rossman, the rejection of the center's hegemony is articulated particularly in some ethnically Russian regions, rather than in ethnic autonomies. Rossman ranks the regions that are partly integrated into trans-national economy (Kaliningrad, Vladivostok, Murmansk, Astrakhan), as well as some of the poorest Russian regions adjacent to Moscow, as the most "anti-Moscow".

Rossman's interpretation of the Moscow-phobia (later in the text referred to as "classic" Moscow-phobia) as a narrative of anti-colonial resistance gravitates towards the Marxist theory of internal colonization, because all five concepts in one way or another are based on the consideration of economic factors. The otherness of the capital (perhaps its cultural otherness in particular) manifests only in the concept of an alienated state within a state.

In order to analyze the Moscow-phobia as an indicator, a sign or a marker of imperial nature of relations between Russian regions, we need to highlight the "concepts" of the phobia typical for provincial Russians unfamiliar with philosophical debates, abstract reviews of (post)colonial studies, or the imperial status of modern Russia. First, we need to determine the role of economic and cultural factors in the intentions and narratives of anti-colonial resistance.

2 Under the comprador capitalism, the sale of natural resources is the basic most profitable kind of economic activity. See: Igor Bestuzhev-Lada, 2007. Ochen uzh kratkaia istoriia chelovechestva s drevneishikh vremen do nashikh dnei i dazhe neskolko dolshe. Moskva. 


\section{Research Design}

As a rule, sociologists analyze the attitudes about Moscow through the survey with direct questionnaire; this method is often criticized in the social sciences (Presniakova, 2006; Rossman, 2011). The phenomenon of the Moscow-phobia in this study however, was revealed accidentally. The main purpose of the research was to analyze the changing regional identity in the Russian province in the context of socioeconomic development of the region ${ }^{3}$.

Regional identity was studied by means of a set of various techniques and methods; the symbolic component of regional identity was reconstructed through projective interviewing (simulation of an open-ended situation) (Burlachuk, 1989). The interviewer recreated the situation of "train car conversations" that involved respondents and their fellow passengers from other Russian provincial cities, from Moscow and from abroad. Interview instructions were based on the principle of free expression, the idea of "Story Telling Techniques". They read as follows: "Imagine that you are taking a train and talking with a fellow passenger from another non-capital city. Please, tell your companion about the place where you live, about your "small homeland".

After the respondent finished the story for a fellow-passenger about his or her place of residence, the interviewer changed the context: "Imagine that your companion got off the train at the nearest station. Now you are talking to another passenger; he or she is from Moscow. Now, please, tell the Muscovite about your city".

The third version of the story, according to the instructions, was designated for a foreign fellow passenger: "Imagine ...."

All the stories (told to all of the three passengers) were recorder and then analyzed (Radina, 2016).

This method of obtaining empirical material is inductive (from empiricism to the theory) and is characteristic of qualitative methodology (Denzin, 2000). Its main advantage is the sensitivity to all manifestations of the empirical field, without the elimination of empiricism (all empirics is analyzed, regardless of whether it is relevant or not to the hypotheses and initial theories).

The "psychology" of this technique lies in the projective nature of the stories. Imagining an encounter with various fellow travelers (provincials, Muscovites and foreign-

3 Political scientists define the territorial identity as "embeddedness of the characteristics and meanings on which the awareness of belonging to the territory is based, in the system of selfidentifications of an individual". It is also defined as "a set of symbolic and ideological systems and meanings associated with the process of interpretation of the regional peculiarity through which the uniqueness of the region acquires the tangible features is the form of images, symbols and myths shared by the members of the regional community". See: Irina Semenenko, (ed.), Identichnost kak kategoriia politicheskoi nauki: slovar terminov i ponjatii. Tom 1. ed. I. Semenenko (Moskva, 2011), 144 - 145. 
ers), the respondents included in their stories social stereotypes and communicative patterns that reflected their attitudes towards the given social groups and territories.

Every story was recorded and later transcribed (typed on a computer) for the subsequent analysis. In 2001-2002, we interviewed in total 515 people of different age groups, different levels of education (from incomplete high school to higher education), who lived in small towns of the Nizhnii Novgorod region and in the city of Nizhnii Novgorod (25\% - young people under 30 years, 35\% - from 31 to 60 years, and 40\% - over 60 years; 49\% women and 51\% men; 20\% - residents of Nizhnii Novgorod, $80 \%$ - residents of small cities in the Nizhnii Novgorod region). In 20142015, we interviewed 366 people altogether (30\% - young people under 30 years, $58 \%$ - from 31 to 60 years, and 12\% - older than 60 years; 63\% women and 37\% men; $27.5 \%$ residents of Nizhnii Novgorod , $72.5 \%$ - residents of small towns and urban-type settlements $)^{4}$.

In 2001-2002, the study was funded by city entrepreneurs and conducted in the course of the Nizhny Novgorod governor elections (business leaders requested an independent analysis of the voters' mood). The study of 2014, which provided an opportunity to compare the characteristics of social structure and the perceptions of the city among the local residents, was supported by the Russian Scientific Foundation.

Thus, 881 people from 16 small, medium, and large cities of the Nizhnii Novgorod region and from the city of Nizhnii Novgorod itself took part in the study.

In 2001-2002 as in 2014-2015, the interviewees for the first stage of the study were selected according to the principle of random sample. After numbers of respondents reached 300, we resorted to the quota sampling technique. As a result, both samples included diverse population groups, yet they did not reflect in detail and in perfect proportions the totality of the inhabitants of the region under study. It should be noted as well, that empirical data for this study came in two separate sets with the time interval more than 10 years. This approach is not typical for applied research in political science in Russia. Nevertheless, it is often used in the social sciences when, on the one hand, the study focuses on the dynamics of some social phenomenon or process, and on the other hand, the standard longitudinal study is quite problematic.

After the transcription and analysis of collected stories, we discovered that the stories about one's "small homeland" told an imaginary Muscovite have peculiar properties and meanings, as the overwhelming majority of the respondents gave their opinions about the life and the society of Moscow rather than simply telling their companions about their hometown in accordance with the conditions of the interview.

4 Nizhnii Novgorod is a Russian city with more than a million residents. It is the industrial center located just over 400 kilometers east of Moscow. In the Soviet times, the city was called Gorky; until 1991 it was closed for foreign visitors. The Nizhnii Novgorod region does not border the Moscow region. 
Importantly, during the projective interviewing the respondent is not guided towards any "correct" answer. The story about one's hometown ("small homeland") based on the respondent's own experiences and woes. The answers reflected the real attitude of the respondent about imaginary fellow passenger. In fact, many respondents referred directly to their own experiences of visiting Moscow or interacting with a Muscovite. A story designed for provincial companion revealed the most significant topics in the context of the development of the region assigned by the author. After interlocutors switched to a Muscovite and a foreigner, the structure and content of the story could change, for example:

Resident of the regional town Bor, male, 31 y. o., professional secondary education.

Story for a fellow passenger from the province: "I am proud of my city. Nizhnii stands on the hills at the confluence of the great rivers of the Oka and the Volga. Thanks to good leadership, our city opened its borders after the Soviet stagnation. The rivers facilitated intensive communication. Our fair is thriving and this is all thanks to the favorable geographical position. The forests are beautiful. The Kremlin is our pride; how many centuries it stands! We are hoping that we will have soon a Palace of Sports and a circus. There are mushrooms, berries, animals."

Story for a muscovite: "Muscovites have nothing to be proud of. When I served in the army, we had a few Muscovites and I could not stand them! I would always put them in place like this: We have GAZ in Nizhnii [Gorky Automobile Factory], and our cars are everywhere. And the automobile glass, I used to say, is manufactured for the whole country at our glass factory. And they were asked: "So, where is this Bor? What is this Bor after all?" And I picked up the first available glass, turned it upside down, pointing at the bottom marked with "Bor" (because they also make glasses at our factory) and said: "this is my Bor; I live there and I am proud of it"”."

Story of a foreigner: "I served in the military in the East (Armenia, Afghanistan, etc.). I remember that when I was arriving home to Nizhnii by train, I had tears in my eyes: I was so bomesick. In the East, we ate so much fruit, and saw the sea. Still, I was looking out of the window at the approaching Nizhnii thinking that there was nothing better. However good it had been abroad, the homeland still pulled me back. Such a bitter feeling of attraction".

For colonial mind, there is no greater distance than between the colony and the metropole, so the Moscow-phobia revealed itself spontaneously during the study, as soon as the interviewee joined into conversation with a Muscovite (Etkind, 2011). It contrasted against the background of more positive topics and subjects, designated for a fellow passenger from the province. Although Nizhnii Novgorod is a busy, densely populated, and expansive city itself, as well as the administrative center managing the whole region, the antipathy of the respondents was directed exclusively to the city of Moscow. It is safe to assume that both the residents of Nizhnii Novgorod and of its subordinate regional towns participating in the study resent the privileged status of the capital and its unfair treatment of Russia's provincial cities. 
In this study on the Russian province, we follow Davidson, who studied the aversion of non-European peoples towards the colonizers (Davidson, 2007:60-75). Moscow-phobia is considered here a marker of colonial relations between the Russian capital and the regions.

We discuss only those stories that the respondents designated for Muscovite, for this article concentrates on the attitudes of provincial Russians towards Moscow and the Muscovites in "colonial coordinates". Further, we analyze the phenomenon of spontaneous phobia of Moscow as a form of colonial relations in the context of different concepts of internal colonialism in order to see which concept is predominantly shared by "provincial public consciousness" today.

\section{Results of the Study}

\subsection{Story for a Muscovite: "Classic Moscow-phobia" According to Rossman}

Analysis of all the stories told to an imaginary Muscovite showed that some of them illustrate the concepts of the Moscow-phobia offered by Rossman 5 .

The concept of a parasitic capital that lives at the expense of the rest of the country is vividly described in the stories from 2001-2002.

"We supply for the Muscovites. They "eat" our labor. Here we produce and they take it away. Earlier, when we went there [to Moscow] for groceries, we were even buying our own produce there. We supply Moscow with produce. But they take a big share for the budget. Moscow does not contribute to the state budget, however" (male, over 60 y. o., incomplete secondary education, town Balakhna, 2002).

It is remarkable that the respondents were friendly and sincere when they engaged in the conversation with a passenger from the province. The switch of interlocutors flipped the content and the tone of stories. Some of the respondents refused to communicate with the Muscovites altogether (both in 2001-2002 and in 2014-2015).

"Moscow is a parasite city. Muscovites have always profited from the regions such as ours, who used to give to Moscow the lion's share of their profits. If you isolate Moscow, it will not be able to provide for itself: it is just a consumer. Our region is self-sufficient. No wonder they called it "a pocket of Russia" since ancient times. Now, when local authorities decide everything (there is no dictatorship of the center), the Nizhnii Novgorod region will become even more progressive" (male, 30 to 60 y.o, higher education, town Bor, 2001).

$\mathbf{5}$ Further in the text we will refer to these concepts simply as the "classic Moscow-phobia". 
As a rule, the concept of Moscow as an alienated "state within a state" was based on the opposition of economies in the capital and in the regions. The respondents described a difficult economic situation of the regions.

"What do I tell him [a Muscovite]? They have all the conditions. Their salaries are much higher, and they still do not like it. Once I spoke to a sales-woman from Moscow; she gets 4-5 thousand rubles, and she does not like it: not enough for restaurants, cafes. I would tell a Muscovite about our life. He would be surprised, that the salary bere is 300-500 rubles. In the best case, 700 rubles. If we were getting 1,5 thousand rubles, it would be possible to get along. The land helps us: it was and it will be feeding us" (male, older than 60, secondary education, town Arzamas, 2002).

Economic inequality lays the foundation for the construction of negative attitudes during social interaction.

"I would not talk with the Muscovites. They have a very high self-esteem. There exist only Muscovites, and all the rest are plebeians for them. We always disliked the Muscovites, so when one wrestler from Moscow lost here, we were so happy and proud of our fighter" (male, 30 to $60 \mathrm{y}$. o., professional secondary education, town Vyksa, 2014).

The concept of alienated Moscow in the Russian province is multifaceted. The respondents understand that the province is also strange for the residents of the capital: "You can lure a Muscovite to come here only with moonshine ..." (male, older than 60, incomplete secondary education, town Arzamas, 2002).

The Muscovites allegedly bring to the regions the comprador capitalism that destroys the hopes of provincial respondents for a better future.

"The Muscovites are buying all our businesses: bankrupt them, suck everything out of them, reduce the wages. There is no order. They are the owners. They are all drug addicts. Everyone has a private jet and they live in the Maldives. They have big business in America. They don't care about our factories; they have purchased them in order to launder money. They have built a new shop to produce kitchen knives, but the output is very small - (...) it does not pay off; it is just a show. The administration goes there almost every week on a tour and they take schoolchildren there, too. In general, there is nothing good about this shop (...), how many millions they "invested" and put in their pockets?!" (male, less than 30 y. o., higher education, town Vacha, 2015).

The Moscow-phobia as a sign of opposition to_political elites living in the capital transforms into the rejection of Moscow as a "foreign city" incapable of taking care of the regions. 
"Of course, Nizhnii Novgorod region is better than Moscow. Only bosses live there. They have long forgotten about us. And here live ordinary people. Everything is quiet and peaceful. I know that the people here will always help me and support me. I gave up hoping for Moscow long ago. You cannot expect anything good from them" (female, over $60 \mathrm{y}$. o., secondary education, town Zavolzhye, 2002).

Ordinary provincial Russians use clichés to describe Moscow as a city of blasphemous demonstrative consumption of the Russian elite ("Muscovites are fattening"). The details in the stories show that the abundance is described quite primitively (as plenty of sausage and vegetable oil).

"Moscow always lived better than any other city in the country. When the sausage in your shops was getting rotten, we did not even have butter. Nevertheless, our region is getting richer now and we'll show the Muscovites! In the distant future though" (male, less than 30 y. o., secondary education, town Bor, 2001).

The concept of a "drain" or a "vacuum" that pulls into the capital the residents of nearby regions is linked not only to economic, but also to the psychological causes. From the point of view of the narrators the people who chase the easier life move to Moscow; the real "working people" stay in the province.

"Every Muscovite is familiar with the life of a village, as almost all of them migrated from the countryside. They started giving themselves airs. My relatives moved there, they like it, but they always come for vacation to the countryside. They have to pay for vegetables and fruits, while we are growing everything ourselves. I do not need this Moscow" (male, 30 to 60 y. o., higher education, town Sergach, 2002).

Some respondents acknowledged that moving to Moscow does not make one automatically richer. Slavery rather than prosperity awaits the provincials in Moscow.

"Our people, workers from Zavolzhye, come to Moscow to build housing for you. They work at the dirtiest plants. The Muscovites value themselves more than us. The authorities are in Moscow and so they invite to come there for some kind of slavery" (male, 30 to $60 \mathrm{y}$. o., secondary education, town Zavolzhye, 2002).

In 2014-2015, the negative attitudes towards Moscow as a drain weaken in intensity. In later years, migration to Moscow is perceived as a forced measure because of the deteriorating socio-economic situation in the region (migration not only to Moscow but to the more prosperous regions in general).

Thus, the forms and concepts of the Moscow-phobia proposed by Rossman as analytical tools, despite their complexity and layering, reveal themselves on the 
level of everyday thinking in the Russian province. The stories were not confined exclusively to the forms of the "classic Moscow-phobia" (Rossman) however. In the narratives addressed to the Muscovites, we discovered other forms of confrontation between the capital and the province.

\subsection{Other Forms of the Moscow-phobia}

Another form of the phobia of Moscow refers to a positive self-presentation, the construction of a positive identity of the region against the background of the negative attitude towards the capital.

"I don't like your city; it has few millions inhabitants. It has so many officials and they do not care about an individual. We live better: we have a better ecology. We relax and relieve stress outdoors. You have some advantages: the shows. And we have only amateur performances; if they are funded, they will get better" (male, over 60 y. o., secondary education, town Zavolzhye, 2001).

The positive image of the province is constructed in opposition to the negative image of Moscow as an ecologically and psychologically disadvantaged region.

"I would compare a Muscovite with a rabbit gradually dying from bondage and its own sewage in a cage. This rabbit needs our freedom. Here is a forest, clean water and the air, in fact, is also clean. Zhukovka, where I live, is located on the outskirts of the city. It is very close to the forest. You get out, pick some mushrooms, and then you are home. Then, there is a pond nearby with fresh fish. People come and say, "Lucky you are, Peter!" And I think so myself. I have all the comforts in the apartment, and there is a real nature just around the corner. I can walk to work. At my age, it's very important" (male, older than 60, higher education, town Vyksa, 2002).

Ecological and psychological preferences allow the residents in the provincial cities to build optimistic plans for the future.

"Of course, Moscow is a big city and it has many advantages. Nevertheless, such small towns as Balakhna have their own pros. First, these towns have much better environmental conditions compared to Moscow. I enjoy living in our city because at any time you are free to go into your own garden, to work there, to relax in nature. In Moscow, it is not possible. The residents of Balakhna are certainly not economically prosperous as the Muscovites, but they are much softer, more friendly. It is easier to communicate with us (the people of Balakhna). Our city is still developing, still growing. I've lived here since 1972 and I am aware of the pace of the progress. I think in the future there will be even more pros" (male, less than 30 y. o., professional secondary education, town Balakhna, 2002). 
Subjectively painful comparison with the capital and social inequality persisting in the provincial picture of the world support this form of the Moscow-phobia from 2001 to 2015. The positive identity of provincial residents in this case is based on the contrasts.

"I would not say anything else about my city, but I would like to add that we are not giving up. We are trying to live decently, no worse than the Muscovites. We will never go to the capital in any price. It is better to live in a private bouse with a plot than among the stones" (female, 30 to $60 \mathrm{y}$. o., secondary education, town Semenov, 2015).

Perception of Moscow as a "state within a state" allows the provincial Russians to consider themselves "salt of the earth" and the "real Russia".

"We can hardly understand each other, because all our life we have been closer to land. It makes our life easier, simpler; it makes us warm. The land gives us its benefits, its riches. Have you ever seen a real live cow? A horse? I remember how a little foal scared me once when I was a child. He stood in a shed behind a fence near his mother-horse, and was invisible. I wanted to peek behind the fence; be looked out at the same time. We met face to face and both got scared! We are still finding ancient coins from seventeenth, eighteenth, nineteenth centuries on our plot" (female, over 60 y. o., secondary education, town Gorodets, 2002).

In the following case, the regional identity is based on the belief that Russia will do just fine without Moscow.

"Our city is one hundred times better. I have been to Moscow; I did not like either the people, or the city. Moscow is not Russia. Russia will do without Moscow; Moscow will not do without cities such as Zavolzhye. Moving to big cities means going the easiest way" (female, 30 to $60 \mathrm{y}$. o., professional secondary education, town Zavolzhye, 2002).

The residents of the regional cities construct a protective boundary between the "alien" Muscovites and "our" provincials. Now, not the Muscovites disregard the provincials, but rather the provincials themselves "monetize" their own provincial hospitality as if they have borrowed the skills to commercialize social relations from the metropolitan residents.

"There is nothing to do for a Muscovite in Nizhnii Novgorod. Therefore, I will not tell anything else here. Thank you for understanding. However, if you decide to come, I will make a tour for you around the Avtozavod [car plant] neighborhood for extra fee" (male, 30 to 60 y. o., higher education, city Nizhnii Novgorod, 2014). 


\subsection{Positive or Neutral Attitude Towards the Center}

Not all the stories told to fellow travelers from Moscow were clearly negative. The content of the "positive" stories was constructed through comparison of one's native city with Moscow as well. This comparison was not in favor of Moscow. The stories retain the traditional content but pass through emotional revaluation. In such cases, the narrators in conversation with a Muscovite could show interest in the capital's resident or even feel sorry for him or her.

"Actually, I feel sorry for the Muscovites. They are very busy; they have no time to communicate with each other. They spent so much time to commute! And it takes me just five minutes to get to my garage and ten minutes to get to work. Our town is quiet and living a measured life" (male, over 60 y. o., professional secondary education, town Arzamas, 2002).

Two topics dominate in content: the ecology and the psychology of the province. The provincial lifestyle is presented as a key feature of the special recreational area designated for metropolitan residents.

"It is so good to get outside early in the morning here. You just want to "drink" this air, not like in a big city. If you go to the bank of the Volga, you can feel that it smells like water and you do not want to leave. The town is very quiet, it may seem like it is in a desert for a person from a big city. Here you can relieve the stress and calm down. Each house has a garden. The sight of the gardens comforts your gaze and you do not want to move away from the window. Now, they are renovating the churches. In the churches your soul is taking rest" (female, over 60 y. o., secondary education, town Balakhna, 2002).

The acceptance of the provincial way of life, reconsideration of the positive aspects of "backward" territories with relatively favorable economic conditions allow the respondents to deconstruct the Moscow-phobia turning it into a generally positive attitude towards the capital.

"I love and respect Moscow. I went to Moscow to buy groceries; now we have everything here. It is quiet and peaceful here and it is noisy in Moscow. I would not like to live there. I am happy that I live here. Here live my grandchildren, my son; everybody is close" (male, older than 60, professional secondary education, town Zavolzhye, 2001).

The economic stability in the region and tourism development allowed the respondents to consider the Muscovites as potential visitors.

"I love Nizhnii Novgorod! This city, my hometown, is small compared with Moscow. Here I was born, started my studies and made a bunch of friends. I adore this city and I do not know why. Although this city is not the capital, it is the most beautiful and wonderful for me. It is impossible to disregard it and drive past this city" (male, less than 30 y. o., secondary education, city Nizhnii Novgorod, 2014). 
In case when a respondent considered the region in the context of tourism development, the story for a Muscovite turned into a kind of an informal advertisement. Then, the positive regional identity was formulated in the context of tourism communication through the perception of the region as a tourist attraction.

"We have a lot of tourists coming from Moscow and the adjacent areas to shop for Khokbloma [wood painting handicraft] products. My uncle who lives in Moscow have been here and has bought many different items to give to his relatives-in-law" (female, less than 30 y. o., professional secondary education, town Semenov, 2015).

\subsection{Dynamics of Transformation of Attitudes Towards the Center (2001/2002 - 2014/2015)}

A little more than a third of all the stories told to a fellow traveler from Moscow in 2001-2002, and in 2014-2015, did not touch the comparison of the capital with the province. Therefore, these narrators did not practice the Moscow-phobia in any of its versions (Figure 1).

Figure 1.

Topics of the stories about "small homeland" told to a Muscovite (\%)

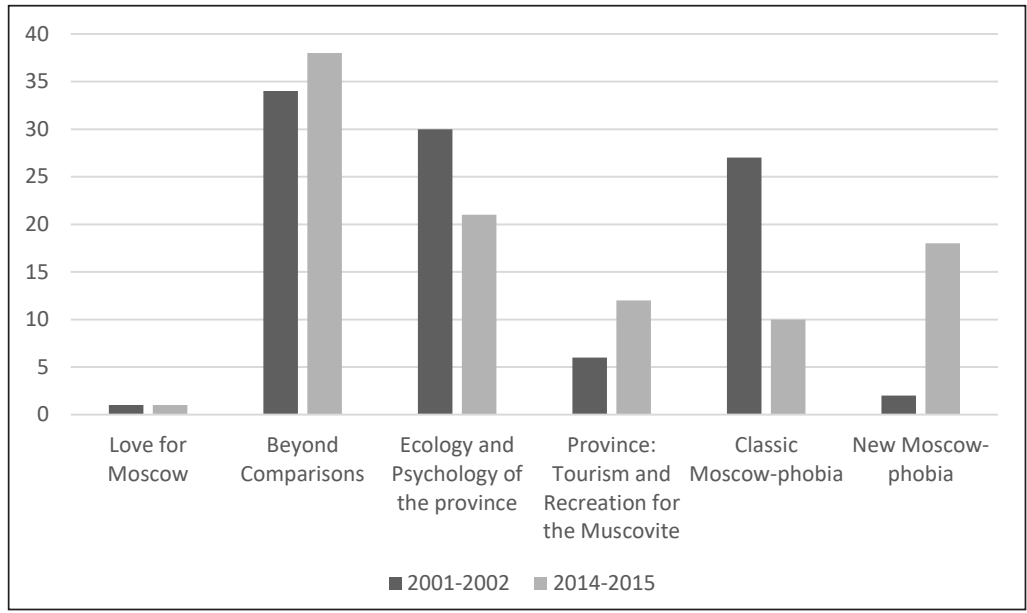

The stories about ecology and psychology of the province told during our study to an imaginary Muscovite fit well into the colonial narrative. The narrators clearly articulated the cultural distance, and often, the relations of domination, between Moscow and the province. They recognized the economic and political priority of the capital emphasizing the special natural and psychological resources of the colonized province. In these stories, the provincial territory was described as valuable and unique, although subordinate to the center. 
A small proportion of the stories focused on the market and even servile relationship between the province and the capital. The respondents told their imaginary companions about their love for Moscow (less than 1\%) and invited the Muscovites to their city as tourists and holidaymakers (see the sections "Love for Moscow" and "Province: Tourism and Recreation").

Another proportion of the stories (about a quarter in 2001-2002 and every tenth story in 2014-2015) illustrated the concepts of the phobia of Moscow described by Rossman. These stories concentrated mainly on economic inequality and economic domination of the capital over the region. It is reasonable to attribute them to the Marxist version of Russian internal colonialism, the one that focuses on economic exploitation.

The culture-centric version of the stories told a Muscovite included a "new phobia of Moscow" focusing on a hypertrophied hyperpositive local identity. The residents contraposed their hometowns to Moscow as the cities that are "not worse", or even better than the capital. In 2001-2002, there were just few of such stories; in 20142015, the stories focusing on the positive provincialism constituted almost one-fifth of the whole sample.

During the studied period, the "classic Moscow-phobia" based on the respondents' reflection on economic inequality, somewhat recedes and is supplanted by the new forms oriented on the articulation of cultural differences as well as the positive positioning of the region on the part of the provincial population.

As for the classic form of the Moscow-phobia, in 2001-2002 as in 2014-2015, the concept of an alienated "state within a state" turned out to be the most comprehensible and the most claimed in making up the stories for a fellow traveler from Moscow (see Figure 2).

Figure 2.

The Moscow-phobia according to Rossmann in the stories about the "small homeland" (\%)

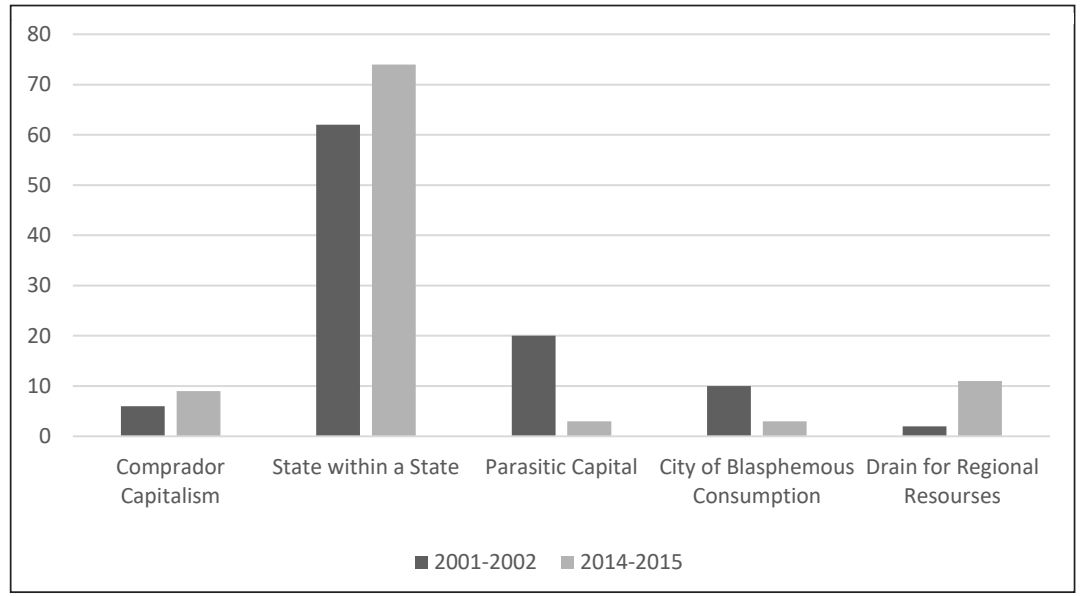


The concept of the parasitic capital was more typical for the stories collected in 2001-2002. The concept of comprador capitalism was almost equally popular in 2001-2002 and in 2014-2015. The concept of Moscow as a city of blasphemous consumption by elites was more common in the stories collected in 2001-2002. Finally, the concept of Moscow as a drain or a vacuum that sucks the resources out of the regions was more common in the stories of 2014-2015.

In order to find out what forms of the Moscow-phobia are typical for various social groups, we analyzed the basic scenarios in terms of gender, age and level of education of their narrators (see Figure 3).

Figure 3.

Social groups focusing on the "classic Moscow-phobia" (\%)

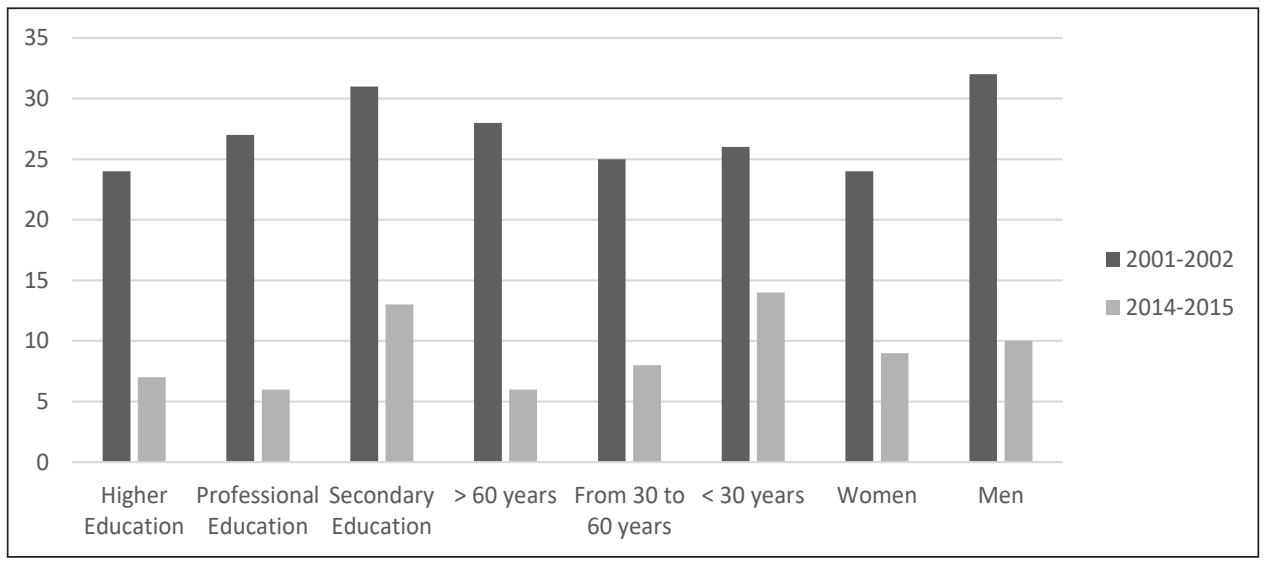

According to Figure 3, in 2001-2002, the men participating in the study more often than women adhered to the classic Moscow-phobia. However, in 2014-2015, the intensity of the Moscow-phobia declined and the positions of men and women in terms of the negative attitudes towards the capital equalized.

In 2001-2002, all age groups almost equally shared the features of the Moscowphobia. In 2014-2015, negative attitudes towards the Muscovites were more characteristic of the younger group participating in the study. In addition, in 2001-2002, the participants with secondary and incomplete secondary education, significantly more frequently adhered to the classic Moscow-phobia. At the same time, the affiliation with male gender group and with the group of less educated respondents (probably also with a lower income) stands out as the most significant characteristics.

Figure 4 shows the quantitative indicators of social groups whose representatives focused on the new forms of the Moscow-phobia. 
Figure 4.

Social groups focusing on the new Moscow- phobia (\%)

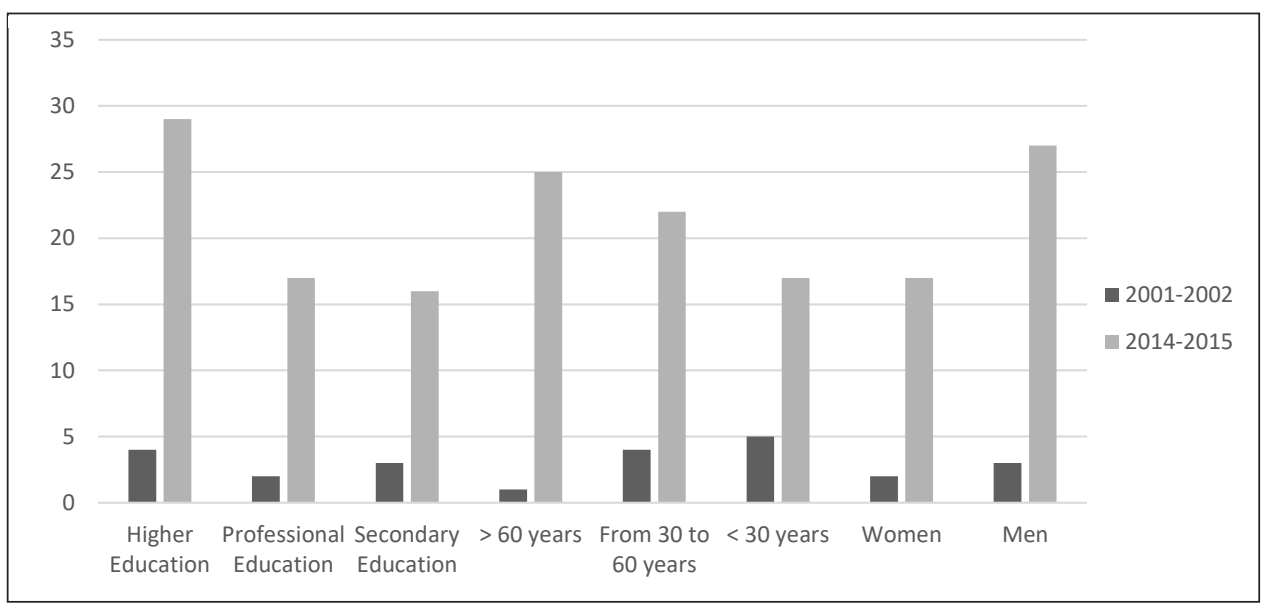

In 2014-2015, men more often than women claimed the priority of their region to Moscow. Age did not prove to be a significant factor for the new Moscow-phobia, although it is possible to consider the tendency towards «maturity» of the respondents in terms of the new forms of the phobia. The level of education on the other hand was a significant factor: the narrators with higher education more frequently presented their region as "no worse" or "even better" than the capital.

The new Moscow-phobia is consistent with the version of the internal colonization of Russia proposed by Etkind. All the stories that we categorized as the "new Moscow-phobia" put forward the reasons why the region is so good; the strengths of the region were described by appealing to history, culture and the development of the region.

In life practice as well as at the level of mental discussions, the two versions of internal colonialism (economic and culture-centric) literally existed in parallel and both revealed in empirical forms. In this study, the empirical results testify to the substitution of the classic Moscow-phobia based on the reflection on economic inequality of the territories inside the empire with a new culture-centric form.

\section{Discussions and Conclusions. The Theories of Internal Colonialism and the Moscow-phobia as it is Practiced: Debates on the "Cultural" and the "Economic"}

Etkind argues that Russian colonial history is almost completely neglected in postcolonial studies (Etkind, 2011). Perhaps the problem is not really the specifics of internal colonization, but rather the fact that the colonized side in Russia underwent some mutation without generating the texts that would be convenient for researchers. 
Following Said, we assume that political action creates the knowledge that determines the behavior of the "internal colonizers" and directs the scientific research, creating a vocabulary and a matrix for understanding of "the Russian hinterland". In the system of knowledge about the Russian province, the postcolonial ideas of "permanent resistance" of the province merge with the colonial idea of the defectiveness of the provincials who refused to migrate to the capital (Pliusnin, 2013). The capital representing the colonial power generates the image of the provincial population. In the eyes of the metropolitan residents, as in the eyes of the Europeans according to Said, provincials are similar to "slaves and monsters" (Said, 1994).

The postcolonialisms of Etkind and Said contradict each other, as Said's colonized people were barbarians for the colonizers, and, according to Etkind, the subjugated people of Russian and other ethnicities were believed to be endowed with higher culture and moral than the elite itself" in the Russian colonial history (Etkind, 2011). Other scholars, such as Liudmila Parts, who analyzed the modern mass culture on the subject of negotiation of "Russianness" between "backward" provinces and the Westernized capital, have recently noted that the province nowadays challenges the right of the center for national authenticity, the right to represent the Russian tradition and moral values (Parts, 2015). When the privilege to characterize the relationships between the colonized territories and the metropole passes to the colonized, the prognostic capabilities of each theory of internal colonialism to describe the reality of colonization become obvious.

As a result, the Moscow-phobia that we identified in empirical data of this study breaks into two distinct forms: the classic, rooted in economic inequality, and the post-colonial, centered on the cultural distance and superiority of the province.

The classic Moscow-phobia, its Marxist version, was more likely to occur in the stories collected in 2001-2002 corresponding to the economic plight of many Russian regions from the late 1990s to the early 2000s. In the Nizhnii Novgorod region, it is also associated with the protest activity of the population (Staroverov, 1993). The new Moscow-phobia especially evident in the stories of 2014-2015 follows the thesis of Etkind on the impact of the discourse about the cultural priority of provincial Russia, represented in the Russian literature of the last three centuries (Etkind, 2011).

We suggest that with the weakening of the economic crisis, colonial relationships between the regions (and how the population perceives them) are reinterpreted and rearticulated in different terms switching from the sphere of economy to the sphere of culture. The temporal distance from the past Soviet experience of central planning of national economy might also be a factor of the citizens' growing hopes for the local authorities to gain independence from the "imperial" center, to improve the living standards in the province, and let the provincial people take hold of the results of their own labor.

Which social groups were more likely to identify and reproduce the narrative of internal colonialism in their stories? Two factors determined the activity of "the heralds of colonial relations": gender and education. Men more often than women tended to 
use the comparison of areas while reflecting on the places of their residence (they practiced both the classic and the new forms of the Moscow-phobia).

The respondents who chose the classic version of the Moscow-phobia more often had an average level of education (secondary education). The respondents with higher education more often made up the stories about "the small homeland" focusing on the cultural superiority over the capital in the context of the new Moscowphobia.

Reflecting on the "cultural distance" as an essential feature of Russian internal colonialism, Uffelmann argued that internal colonization is not just a metaphor, but a mechanism for reproduction of cultural distances in the colonized territories (Uffelmann, 2012:53-104). Basing on this statement, the constantly reproduced cultural distances between the regions (under the dominance of the center) testify to the continuation of colonization, to the continuous building of empire.

Having analyzed the real and fluid phenomenon of the Moscow-phobia that parallels the practices of colonial self-understanding, we can assume that the contemporary Russia incorporates both trends of decolonization and reproduction of colonialism. The decolonization includes the anti-colonial resistance and the search for new identities as well as the voice by the former subjects to internal colonization. The reproduction of colonialism implies the construction and acceptance of the cultural distances under the recognition of the prerogative of the center to define the truth.

\section{References}

1. Ashcroft, B.; Griffiths, G. and Tiffin, H. (1995). The post-colonial studies reader. London: Routledge.

2. Bestuzhev-Lada, I. (2007). Ochen uzh kratkaia istoriia chelovechestva s drevneishikh vremen do nashikh dnei i dazhe neskolko dolshe [A Really Short History of Humanity from Ancient Times to Present Days and Even A Little Bit More]. Moscow: Institut ehkonomicheskih strategij.

3. Blauner, B. (1972). Racial oppression in America. New York: Harper \& Row.

4. Bowels, P. (1989). Peripheral Capitalist Development Revisited. Studies in Political Economy, 28: 183-203.

5. Burlachuk, L. and Morozov, S. (1989). Slovar-spravochnik po psikhologicheskoi diagnostike [Glossary-Handbook on Psychological Diagnostics]. Kiev: Naukova dumka.

6. Calvert, P. (2010). Internal colonization, development and environment. Third World Quarterly, 22 (1): 51-63.

7. Campbell, S. (2013). The Changing Role and Identity of Capital Cities in the Global Era. Logos, 4 (94): 57-108.

8. Clark, K. (2011). Moscow, the Fourth Rome: Stalinism, Cosmopolitanism, and the Evolution of the Soviet Culture 1931-1941. Harvard University Press.

9. Davis, M. (2006). City of Quartz: Excavating the Future in Los Angeles. New York: Verso. 
10. Davidson, A. (2007). Imperskoe nasledie v XXI veke [Imperial Legacy in the Nineteenth Century], in: Kliamkin, I. (Ed.). Posle imperii [After the Empire]. Moscow: Fond-"Liberalnaya-missiya".

11. Denzin, N. K. and Lincoln, Y. S. (2000). Introduction: The discipline and practice of qualitative research, in: N. K., Denzin and Y. S., Lincoln (Eds.). The handbook of qualitative research. Second edition. Thousand Oaks, CA: Sage, 1-28.

12. Eisenstadt, S. N. (1981). Cultural Orientations and Center-Periphery in Europe in a Comparative Perspective, in: Torsvik, P. (Ed.). Mobilization, Center-Periphery Structures and Nation-Building: a Volume in Commemoration of Stein Rokkan. Scandinavian University Press.

13. Etbington, P. J. (2001). The public City: The Political Construction of Urban Life in San Francisco, 1850-1900. Los Angeles: UC Press.

14. Etkind, A. (2011). Internal Colonization: Russia's Internal Experience. Cambridge: Polity Press.

15. Etkind, A.; Uffelman, D. and Kukulin, I. (Eds.) (2012). Tam, vnutri. Praktiki vnutrennei kolonizatsii $v$ kulturnoi istorii Rossii [Inside there: The practice of internal colonization in the cultural history of Russia]. Moscow: Novoe literaturnoe obozrenie.

16. Etkind, A.; Uffelman, D. and Kukulin, I. (2013). Vnutrenniaia kolonizatsiia Rossii: Mezhdu praktikoi i voobrazheniem [Internal colonization in Russia: Between practice and imagination]. Political conceptology: the journal of interdisciplinary research, 2: 31-56.

17. Fanon, F. (2008). Black Skin, White Masks. Pluto Press.

18. Fisher-Tine, H. (2010). Postcolonial Studies. European History Online, Leibniz Institute of European History. http://ieg-ego.eu/en/threads/theories-and-methods/postcolonial-studies. (Accessed 9 September 2017)

19. Friedmann, J. (1966). Regional Development Policy: A Case Study of Venezuela. MIT Press.

20. Gouldner, A. W. (1978). Stalinism: A Study in Internal Colonialism. Telos, 34, 1978: 5-48.

21. Gramsci, A. (1957). The Modern Prince and Other Writings. New York: International Publishers.

22. Grois, B. (1993). Utopiia i obmen [Utopia and Exchange]. Moscow: Znak.

23. Habermas, J. (2004). The theory of communicative action. Cambridge: Polity Press.

24. Hartshorne, R. (1950). The functional approach in political geography. Indianapolis, Md: Bobbs-Merrill.

25. Harvey, D. (2003). Paris. Capital of Modernity. New York \& London: Routledge.

26. Hechter, M. (1975). Internal Colonialism. The Celtic Fringe in the British Development. London: Routledge \& Kegan Paul.

27. Kliuchevskii, V. (1956). Kurs russkoi istorii [Russian History Course]. Moscow: Gospolitizdat.

28. Lenin, V. I. (1971). Razvitie kapitalizma v Rossii [Capitalism Development in Russia], in: Lenin, V. Polnoe sobranie sochinenii. In-t marksizma-leninizma pri TsK KPSS. T. 3. 5-e izd. [Complete Works. Institute of Marxism and Leninism under CPSU Central Committee, vol.3, $5^{\text {th }}$ edition]. Moscow: Politizdat, 1-609. 
29. Netzloff, M. (2003). England's internal colonies: class, capital, and the literature of early modern English colonialism. New York: Palgrave Macmillan.

30. Onega, S. and Stotesbury, J. (2002). London in Literature: Visionary Mappings of the Metropolis, in: Onega, S. and Stotesbury, J. (Eds.). Heidelberg: University of Heidelberg Press.

31. Parts, L. (2015). Topography of Post-Soviet Nationalism: The Provinces - the Capital - the West. Slavic Review, 74 (3): 509.

32. Pliusnin, Iu. (2013). «Svoi» i «chuzhie» v russkom provintsialnom gorode ["We" and "Others" in a Russian Provincial City]. Mir Rossii, 3: 60-93.

33. Prebish, R. (1992). Periferiinii kapitalizm: est li emu alternativa? [Capitalism of the Periphery: Is there an alternative to this?]. Moscow: Institute of Latin America, Russian Academy of Science.

34. Presniakova, L. (2006). Otnoshenie rossiian k Moskve i moskvicham [Attitudes of Russians towards Moscow and the Moscovites]. FOM database. http://bd.fom.ru/ report/cat/mos/dd063923. (Accessed 20 March 2017)

35. Radina, N. (2016). A provincial Russian town: images for insiders and outsiders. The Russian Journal of Communication, 8 (1): 67-79.

36. Rokkan, S. and Urwin, D. W. (1996). The Politics of Territorial Identity: Studies in European Regionalism. London: Sage Publications.

37. Rodoman, B. B. (1996). Vnutrennii kolonializm v sovremennoi Rossii [Internal Colonialism in Modern Russia], in: Zaslavskaia, T. and Arutiunian, L. (Eds.). Kuda idiot Rossiia? Sotsialnaia transformatsiia postsovetskogo prostranstva [Where is Russia going? Social Transformation of Post-Soviet Space]. Moscow: Aspekt Press, 94-102.

38. Rossman, V. (2004). Regiony razliubili Moskvu [Regions Don't Love Moscow Anymore]. Moskovskii Komsomolets, 2004, 8 September, 2.

39. Rossman, V. (2011). Pochemu Rossiia nenavidit Moskvu? [Why Russia Hates Moscow]. Komsomolskaia Pravda, 2011, 3 September. http://www.politonline. ru/provocation/9192.html. (Accessed 18 January 2017)

40. Rossman, V. (2013). Stolitsy: ikh mnogoobrazie, zakonomernosti razvitiia $i$ peremeshcheniia [Capitals: Diversity, Patterns of Development, and Movement]. Moscow: Izdatelstvo instituta gajdara.

41. Rossman, V. (2014). V poiskakh Chetviortogo Rima: Rossiiskie debaty o perenose stolicy [In Search for the Fourth Rome: Russian Debates Around the Moving of the Capital]. Moscow: Izdatelskij dom vysshej shkoly ehkonomiki.

42. Said, E. W. (1994). Culture and Imperialism. New York: Vintage Books.

43. Said, E. W. (1998). Between Worlds. Edward Said Makes Sense of His Life. London Review of Books, 20 (9): 3-7.

44. Said, E. W. (2003). Orientalism. London: Penguin Books.

45. Spivak, G. C.; Condee, N.; Ram, H.; Chernetsky, V. (2006). Are We Postcolonial? Post-Soviet Space. PMLA, 121 (3): 828-830.

46. Spivak, G. C. (1998). Can the Subaltern Speak?, in: Nelson, C. and Grossberg, L. (Eds.). Marxism and the Interpretation of Culture. University of Illinois Press.

47. Staroverov, Iu. (1993). God utrachennykh illiuzii [The Year of Lost Illusions]. Novaia gazeta, 1993, no.145. http://novayagazeta-nn.ru/2012/263/god-utrachennyh-illjuzii.html. (Accessed 14 January 2017) 
48. Steinman, E. W. (2016). Decolonization Not Inclusion: Indigenous Resistance to American Settler Colonialism. Sociology of Race and Ethnicity, 2 (2): 219 -236.

49. Taylor, P. J.; Catalano, G. and Walker, D. R. F. (2002). Exploratory Analysis of the World City Network. Urban Studies, 39: 2377-2394.

50. Uffelmann, D. (2012). Podvodnye kamni vnutrennei (de)kolonizatsii Rossii [Pitfalls of Russian Internal Colonization], in: Etkind, A.; Ufflman, D. and Kukulin, I. (Eds.). Tam, vnutri: praktiki vnutrennei kolonizatsii v kulturnoi istorii Rossii [Inside There: The Practice of Internal Colonization in Russian Cultural History]. Moscow: Novoe literaturnoe obozrenie.

51. Vagin, V. (1997). Russkii provintsialnii gorod: kliuchevye elementy zhizneustroistva [Russian provincial city: key elements of livelihood]. Mir Rossii, 4: 53-88.

52. Vakser, A. Z. (2006). Leningrad poslevoennyi: 1945 - 1982 gody [Post-bellum Leningrad: 1945 - 1982]. Saint Petersburg: Ostrov.

53. Wallerstein, I. M. (2004). World-systems analysis: An introduction. Duke University Press.

54. Walls, D. (2008). Central Appalachia: Internal Colony or Internal Periphery? Sonoma State University. http://web.sonoma.edu/users/w/wallsd/internal-colony. shtml. (Accessed 26 April 2017)

55. Zubarevich, N. (2010). Regiony Rossii: neravenstvo, krizis, modernizatsiia [Russian Regions: Inequality, Crisis, and Modernization]. Mosow: Nezavisimyj institut socialnoj politiki. 
Izvorni znanstveni rad

Nadezhda K. Radina

Visoka škola ekonomije pri Nacionalnom istraživačkom sveučilištu, Odsjek društvenih znanosti, Nižnji Novgorod, Rusija

e-mail: rasv@yandex.ru

Mariia V. Koskina

Državno sveučilište New York u Binghamtonu, Odsjek povijesti, Binghamton, SAD

e-mail: mariakoskina00@gmail.com

\section{Unutarnja kolonizacija i fenomen fobije prema Moskvi u ruskoj provinciji}

\section{Sažetak}

Članak predstavlja rezultate empirijskog istraživanja društvenog fenomena fobije prema glavnom gradu Moskvi. Provedeno je 2002. i 2014. godine u Nižnjenovgorodskoj oblasti i uključuje 881 intervju. Analiza se naslanja na tezu Aleksandra Etkinda da unutarnja kolonizacija proizvodi kulturnu distancu.

Rezultati se tumače u svjetlu dviju teorija unutarnje kolonizacije, marksističke i postkolonijalne. Prethodno je Rossman opisao pet oblika fobije prema Moskvi, koji se temelje na teritorijalnoj ekonomskoj nejednakosti i političkoj hegemoniji centra.

Ovo istraživanje proširuje taj popis novim oblicima, temeljem izjava ispitanika da se njihova nelagoda temelji na kulturnoj distanci i dominaciji provincije nad glavnim gradom.

Stoga je glavna teza ovoga članka da su u suvremenoj Rusiji istovremeno prisutna oba trenda u odnosu centra (glavnoga grada) i periferije (regija), i dekolonizacija i obnavljanje unutarnje kolonizacije.

Ključne riječi: unutarnja kolonizacija, fobija prema glavnom gradu Moskvi, glavni grad, teritorijalna nejednakost. 